\title{
MODEL FUNGSI PRODUKSI DAN RISIKO PADA USAHA PEMBENIHAN LELE DUMBO DI DESA JOHO, WATES, KEDIRI
}

\author{
Mariyana Sari ${ }^{a}$, Wildan Al Farizi ${ }^{a}$, Supriyadi ${ }^{b, *}$, Diana Aisyah ${ }^{c}$, Chusnia Asshovani ${ }^{\text {b }}$ \\ ${ }^{a}$ Agrobisnis Perikanan, Fakultas Perikanan dan Ilmu Kelautan, Universitas Brawijaya \\ Jl. Veteran Malang, Jawa Timur, Indonesia \\ ${ }^{b}$ PSDKU Sosial Ekonomi Perikanan, Fakultas Perikanan dan Ilmu Kelautan, Universitas Brawijaya \\ J1. Pringgondani, Mrican, Mojoroto, Kediri, Jawa Timur, Indonesia \\ cPSDKU Akuakultur, Fakultas Perikanan dan Ilmu Kelautan, Universitas Brawijaya \\ J1. Pringgondani, Mrican, Mojoroto, Kediri, Jawa Timur, Indonesia \\ *Koresponden penulis: supriyadi67@ub.ac.id
}

\begin{abstract}
Abstrak
Penggunaan input produksi pada usaha pembenihan ikan lele dumbo dapat menambah risiko produksi dan juga dapat mengurangi risiko produksi. Penelitian ini bertujuan untuk menganalisis pengaruh input produksi terhadap risiko produksi yang dihadapi oleh pembudidaya benih ikan lele dumbo di Desa Joho, Wates, Kediri. Penelitian ini mengambil 30 responden yang dilakukan secara snowball sampling sedangkan metode analisis data menggunakan model Just and Pope. Pengolahan data menggunakan alat bantu Microsoft Excel 2016 dan software statistic R-Studio 4.0.1. Hasil perhitungan menunjukkan input produksi pakan buatan, indukan dan obat-obatan mempengaruhi produktivitas secara nyata. Peningkatan indukan secara nyata menurunkan risiko produksi, dan peningkatan obat-obatan secara nyata meningkatkan risiko produksi. Rekomendasi kebijakan dari penelitian ini adalah pembatasan penggunaan input produksi yang dapat menimbulkan risiko produksi, dan penerapan CBIB (Cara Budidaya Ikan yang Baik) berdasarkan kebijakan dari Direktorat Jenderal Perikanan Budidaya (DJPB).
\end{abstract}

Kata Kunci : input produksi, Just and Pope, Pembenihan lele, Statistik R-Studio

\begin{abstract}
The use of production inputs on African catfish hatchery business can cause production risks and also can reduce production risks. This study aims to analyze the effect of production inputs cause on production risks faced by African catfish hatchery cultivators in Joho Village, Wates, Kediri. This study took 30 respondents conducted by snowball sampling and the data analysis method used Just and Pope model. Data processing tools used Microsoft Excel 2016 and R-Studio 4.0.1 statistical software. The results showed production inputs of artificial feed, brood stock, and drugs significantly affect productivity. Increased of brood stock significantly decreases production risk, and increased of medicines significantly increase production risk. The policy recommendations of this study are limiting the use of production inputs that could pose production risk, and CBIB implementation based on the policy of Directorate General of Aquaculture (DJPB).
\end{abstract}

Keywords: Production input, Just and Pope, Catfish hatchery, R-Studio Statistics

\section{PENDAHULUAN}

Sektor perikanan merupakan semua kegiatan yang berhubungan dengan pengelolaan dan pemanfaatan sumber daya ikan dan lingkungannya mulai dari pra-produksi, produksi, pengolahan sampai dengan pemasaran yang dilaksanakan dalam suatu sistem bisnis perikanan.

Sektor perikanan dibagi menjadi dua bagian, yaitu sektor perikanan tangkap dan sektor perikanan budidaya. Berdasarkan peta potensi perikanan budidaya di KKP, seluruh pulau di Indonesia berpeluang menjadi tempat pembudidayaan, baik untuk budidaya perikanan air tawar, air payau, dan juga laut. Salah satu daerah di Jawa Timur yang dapat dijadikan daerah pengembangan sektor budidaya perikanan air tawar yaitu Kabupaten Kediri.

Kabupaten Kediri memiliki luas kotor tempat pembenihan baik dari Balai maupun UPR (Unit Pembenihan Rakyat) sebesar 211,70 hektare dengan jumlah pembenihan sebanyak 2.551 unit. Sedangkan tingkat kebutuhan benih ikan lele di Jawa Timur tergolong tinggi, yaitusebanyak9.453.217.030 ekor[1]. Kondisi tersebut menunjukkan bahwa terdapat peluang 
untuk mengembangkan lebih lanjut usaha pembenihan ikan lele[2].

Alasan untuk melakukan usaha pembenihan ikan lele karena secara teknis mudah dan secara ekonomi sangat menguntungkan. Selain ada beberapa keuntungan yang diberikan, tetapi sebenarnya usaha pembenihan ikan lele lebih rentan terhadap risiko tinggi dibandingkan usaha pembesaran ikan lele jika tidak dikelola dengan baik. Faktor yang diindikasi sebagai sumber risiko produksi sehingga berpengaruh buruk dalam menghasilkan output produksi adalah benih ikan lele yang dipelihara masih dalam keadaan yang kecil, serta masih rentan terhadap sumber risiko perubahan suhu air, kualitas air, hama dan penyakit, kanibalisme serta penggunaan input produksi. Menurut [3], faktorfaktor risiko produksi dapat digolongkan menjadi dua, yaitu faktor risiko terkendali yang berasal dari variasi penggunaan input produksi dan faktor tidak terkendali yang berasal dari perubahan musim, penyakit, dan kualitas sumber daya manusia.

Dalam penggunaan faktor atau input produksi, terdapat faktor produksi atau input yang dapat menimbulkan risiko produksi tetapi ada juga faktor produksi atau input yang dapat mengurangi risiko produksi[4]. Oleh karena itu penting untuk menganalisis faktor-faktor produksi yang ada pada usaha budidaya pembenihan ikan lele dumbo. Hal tersebut untuk mengetahui pengaruh yang terjadi pada masingmasing faktor produksi yang mempengaruhi produktivitas benih ikan lele dumbo yang dihasilkan. Selain itu, harga output dan harga input juga dapat mempengaruhi penerimaan pembudidaya dan biaya produksi. Oleh karena itu, besar kecilnya penerimaan pembudidaya dan biaya produksi mempengaruhi pendapatan yang diterima oleh pembudidaya. Penelitian ini bertujuan untuk menganalisis pengaruh faktorfaktor produksi terhadap risiko produksi yang dihadapi oleh pembudidaya benih ikan lele dumbo di Desa Joho, Wates, Kediri.

\section{METODE}

Penelitian ini dilaksanakan di Desa Joho Kecamatan Wates Kabupaten Kediri. Pemilihan lokasi dilakukan secara sengaja (purposive), dengan pertimbangan bahwa Desa Joho Kecamatan Wates merupakan salah satu desa yang memiliki kelompok pembudidaya ikan pada jenis usaha pembenihan lele dumbo dan Desa Joho masih bisa dikunjungi oleh masyarakat pendatang dengan penerapan protokol kesehatan pada masa pandemi Covid19.Penelitian ini dilakukan di Pokdakan Berkah Lele dan Sumber Rejeki dengan pertimbangan bahwa kedua kelompok ini merupakan kelompok yang masih aktif dalam usaha pembenihan ikan lele dumbo.

Metode pengambilan responden dilakukan dengan metode snow ball sampling. Penelitian ini mengambil 30 responden, yang paling aktif dari kelompok tersebut. Pengambilan contoh dengan teknik ini, dikarenakan populasi pada pembudidaya benih ikan lele dumbo mempunyai perilaku yang relatif sama (homogen). Dalam teorema batas sentral (central limit theorem) populasi yang relatif homogen terdistribusi mendekati normal dengan ukuran contoh $(\mathrm{n} \geq$ 30) [5]. Pengolahan dan analisis data dalam penelitian ini dilakukan secara kuantitatif. Analisis data secara kuantitatif yang digunakan meliputi analisis faktor-faktor produksi yang mempengaruhi produksi benih ikan lele dumbo dengan menggunakan alat bantu model fungsi risiko produksi Just and Pope. Data dan informasi yang telah didapat akan langsung diolah dengan menggunakan alat bantu Microsoft Exel 2016 dan software statistic $R$ Studio 4.0.1.

Model fungsi produksi dan risiko yang digunakan adalah Just And Pope dalam bentuk fungsi Cobb-Douglas [6]. Secara sistematis model fungsi produksi Just and Pope. yaitu:

$\mathrm{Y}=\mathrm{f}(\mathrm{x}, \boldsymbol{\beta})+\mathrm{h}(\mathrm{x}, \theta) \mathrm{e}$

Keterangan:

$\begin{aligned} \mathrm{Y}= & \text { Hasil Produktivitas } \\ \mathrm{f}= & \begin{array}{l}\text { Bentuk hubungan yang } \\ \text { mentransformasikan raktor- } \\ \text { faktor produksi dalam rata }- \text { rata }\end{array} \\ & \text { hasil produktivitas } \\ \mathrm{h}= & \begin{array}{l}\text { Bentuk hubungan yang } \\ \text { mentransformasikan } \\ \text { faktor- } \\ \\ \text { faktor produksi dalam variance } \\ \text { hasil produktivitas }\end{array} \\ \mathrm{x} & \begin{array}{l}\text { Faktor- faktor produksi yang } \\ \text { digunakan dalam proses }\end{array} \\ \text { produksi (input) } & \text { Besaran yang akan diduga } \\ \beta, \theta= & \text { Error }\end{aligned}$

Fungsi Produksi:

$\mathrm{Y}=\mathrm{f}(\mathrm{x})$

$\operatorname{Ln} Y_{i}=\operatorname{Ln} \beta_{0}+\beta_{1} \operatorname{Ln} X_{1 i}+\beta_{2} \operatorname{Ln} X_{2 i}+\beta_{3} \operatorname{Ln} X_{3 i}+$ $\beta_{4} \operatorname{Ln} X_{4 i}+\epsilon$

Fungsi Variance Produktivitas :

$\sigma^{2}=\mathrm{f}(\mathrm{x})$ 
$\operatorname{Ln} \sigma^{2} Y_{i}=\operatorname{Ln} \theta_{0}+\theta_{1} \operatorname{Ln} X_{1 i}+\theta_{2} \operatorname{Ln} X_{2 i}+\theta_{3} \operatorname{Ln} X_{3 i}+$ $\theta_{4} \operatorname{Ln} X_{4 i}+\epsilon$

Variance Produktivitas :

$\sigma^{2} Y_{i}=(Y i-\hat{Y} i)^{2}$

Keterangan :

$$
\begin{aligned}
\mathrm{Y} & =\begin{array}{l}
\text { Produktivitas benih ikan lele } \\
\text { dumbo }\left(\mathrm{ekor} / \mathrm{m}^{2}\right)
\end{array} \\
\mathrm{Y} & \begin{array}{l}
\text { Produktivitas benih ikan lele } \\
\text { dumbo rata-rata }\left(\mathrm{ekor} / \mathrm{m}^{2}\right)
\end{array} \\
\mathrm{Y} & \begin{array}{l}
\text { Produktivitas benih ikan lele } \\
\text { dumbo dugaan }\left(\mathrm{ekor} / / \mathrm{m}^{2}\right)
\end{array} \\
\mathrm{Y} & \text { Pakan Buatan }\left(\mathrm{kg} / \mathrm{m}^{2}\right) \\
\mathrm{X}_{1} & \text { Indukan }\left(\text { pasang } / \mathrm{m}^{2}\right) \\
\mathrm{X}_{2} & = \\
\mathrm{X}_{3} & \text { Tenaga kerja }\left(\mathrm{HOK} / \mathrm{m}^{2}\right) \\
\mathrm{X}_{4} & \text { Obat-obatan }\left(\mathrm{ml} / \mathrm{m}^{2}\right) \\
\beta_{1}, \beta_{2}, . \beta_{4}= & \text { Koefisien parameter dugaan } \\
& \text { input produksi } \mathrm{X}_{1}, \mathrm{X}_{2}, \\
& \mathrm{X}_{3}, \ldots \mathrm{X}_{4} \\
\theta_{1}, \theta_{2}, \theta_{4}= & \text { Koefisien parameter dugaan } \\
& \text { input risiko produksi } \mathrm{X}_{1}, \mathrm{X}_{2}, \\
& \mathrm{X}_{3}, \ldots \mathrm{X}_{4}
\end{aligned}
$$

Untuk memperoleh validitas hasil pengujian ekonometrik menggunakan metode Ordinary Least Square(OLS) untuk memperoleh nilai estimasi fungsi produksi yang BLUE (Best Linear Unbiased Estimation) [7]. Menurut [8], pengujian pada penyimpangan asumsi klasik digunakan untuk mendapatkan model terbaik untuk melakukan pendugaan. Pengujian dilakukan untuk kedua model fungsi produksi sekaligus fungsi variance. Kemudian dilakukan uji goodness of fitseperti koefisien determinasi $\left(\mathrm{R}^{2}\right)$, uji $\mathrm{F}$, dan uji t.

Koefisien determinasi $\left(\mathrm{R}^{2}\right)$ untuk mengukur kemampuan model menjelaskan variasi variabel bebas. Adjusted R Square digunakan untuk menentukan nilai koefisien determinasi $\left(\mathrm{R}^{2}\right)$. Uji $\mathrm{F}$ menunjukkan semua variabel independen (bebas) berpengaruh secara bersama-sama terhadap variabel dependen (terikat) jika nilai $\mathrm{F}$ hitung > F tabel maka. Uji t menunjukkan variabel independen (bebas)secara parsial berpengaruh terhadap variabel dependen (terikat) jika t hitung $>\mathrm{t}$ tabel.

\section{HASIL DAN PEMBAHASAN}

Analisis faktor-faktor yang mempengaruhi risiko produksi benih ikan lele di Desa Joho Kecamatan Wates Kabupaten Kediri dilakukan dengan menggunakan model Just and Pope yang dikombinasikan dengan fungsi $C o b b$-Douglas. Model Just and Pope ini dapat menjelaskan bagaimana pengaruh dari faktor-faktor produksi terhadap hasil produksi dan bagaimana pengaruh dari faktor-faktor produksi terhadap risiko produksi yang ditunjukkan dari nilai variance produktivitasnya.

Model Just and Pope ini akan menghasilkan dua fungsi, yaitu fungsi produktivitas rata-rata benih ikan lele dan fungsi variance produktivitas benih ikan lele. Faktorfaktor produksi yang digunakan dalam penelitian ini sebagai penduga yaitu faktor pakan buatan, indukan, tenaga kerja dan obat-obatan. Faktorfaktor tersebut akan dianalisis menggunakan program R Studio 4.0.1. Tahapan analisis yang lakukan yaitu pertama melakukan uji asumsi klasik, menguji nilai $R^{2}$, menguji nilai $F$, menguji nilai $t$, dan menguji sensitivitas dari masing-masing faktor terhadap tingkat produktivitas benih ikan lele maupun risiko produksi benih ikan lele.

\section{Uji Asumsi Klasik}

Uji asumsi klasik dilalukan sebelum melakukan pengujian regresi. Menurut [9], uji asumsi klasik meliputi uji normalitas, uji heterokedastisitas, uji auto korelasi, uji multikolinieritas, dan uji linieritas jika terpenuhi maka estimasi dengan Ordinary Least Square (OLS) akan BLUE (Best Linear Unbiased Estimation).

\section{Uji Normalitas}

Menurut[10], model regresi linier wajib menggunakan data yang terdistribusi normal. Pengujian normalitas ini dilihat pada grafik normal Q-Q dan Shapiro-Wilk normality test. Hal ini dibenarkan oleh pernyataan [11], uji Shapiro-Wilk merupakan metode pengujian normalitas yang digunakan secara terbatas untuk sampel < 50 agar menghasilkan keputusan yang akurat. [12,13]menyebutkan bahwa uji normalitas yang lebih efisien untuk data $<50$ adalah uji Shapiro-Wilk. [14] menyatakan bahwa Shapiro-Wilk menunjukkan hasil distribusi normal yang terbaik kemudian diikuti oleh uji Lilliefors dan uji Kolmogorov-Smirnov.

Berdasarkan hasil analisis, dapat diketahui pada Gambar 1 bahwa pada model fungsi produktivitas dan variance produktivitas titiktitik menyebar di sekitar garis dan mengikuti arah diagonal, dengan demikian dapat disimpulkan bahwa nilai residual pada analisis data tersebut terdistribusi normal. Hasil penelitian [15] menunjukkan bahwa uji normal probability plot (QQ-Plot) yang dilakukan pada nilai residual pada model regresi 
memperlihatkan bahwa titik-titik yang ada mendekati garis diagonalnya sehingga dapat disimpulkan bahwa nilai residual terdistribusi normal. Selain itu, uji normalitas pada penelitian ini dapat dipertegas oleh hasil Shapiro-Wilk normality test dengan $p$-value sebesar 0.6352 yang artinya $p$-value $>0,05$ sehingga data tersebut dikatakan terdistribusi normal. [16,15]menambahkan bahwa perhitungan data menggunakan $\mathrm{R}$-studio dengan output $\mathrm{p}$-value lebih besar dari taraf signifikansi 0,05 maka data sudah mengikuti distribusi normal.

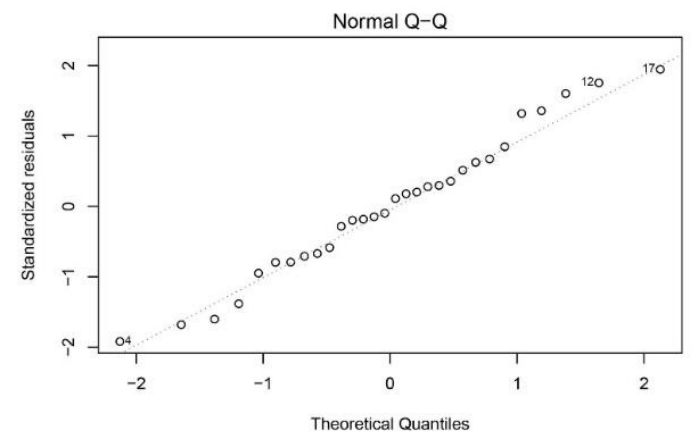

Gambar 1. Grafik Normal Q-Q

\section{Uji Heteroskesdastisitas}

Pengujian heteroskedastisitas

dilakukan untuk menguji apakah dalam model regresi terdapat error atau varians konstan dari residual antara satu pengamatan ke pengamatan lainnya. [9] menambahkan bahwa untuk mendeteksi ada tidaknya heterokedastisitas ada dua cara yang dapat dilakukan, yaitu metode grafik dan uji statistik. Metode uji statistik yang digunakan untuk pendeteksian ada tidaknya heteroskedastisitas adalah uji park dan uji Breusch Pagan Godfrey [18,19]. Pendeteksian masalah heteroskedastisitas menggunakan Breusch Pagan test [20,21]. Menurut [22], metode yang digunakan untuk mendeteksi adanya heteroskedastisitas adalah metode uji Breusch Pagan Godfrey (BPG) dengan taraf nyata $\alpha=0,05$ menggunakan bantuan software $\mathrm{R}$.

Berdasarkan hasil analisis, dapat diketahui pada Gambar 2 bahwa pada model fungsi produktivitas dan variance produktivitas titiktitik menyebar secara merata dan tidak terdapat pola yang jelas, dengan disimpulkan bahwa tidak terjadi heterokedastisitas. Sedangkan berdasarkan Breusch-Pagan test didapatkan pvalue sebesar 0.9467 , artinya $p$-value $>0,05$ sehingga data tersebut dikatakan tidak terjadi heterokedastisitas. [16] menyatakan bahwa uji heteroskedastisitas menggunakan BreuschPagan test dengan P-value yang dihasilkan lebih besar dari tingkat signifikansi 0,05 maka tidak terjadi heteroskedastisitas pada data. [15]menambahkan bahwa residual tidak terjadi heteroskedastisitas dan asumsi non heteroskedastisitas terpenuhi karena nilai $p$ value > tingkat signifikansi 0,05 .

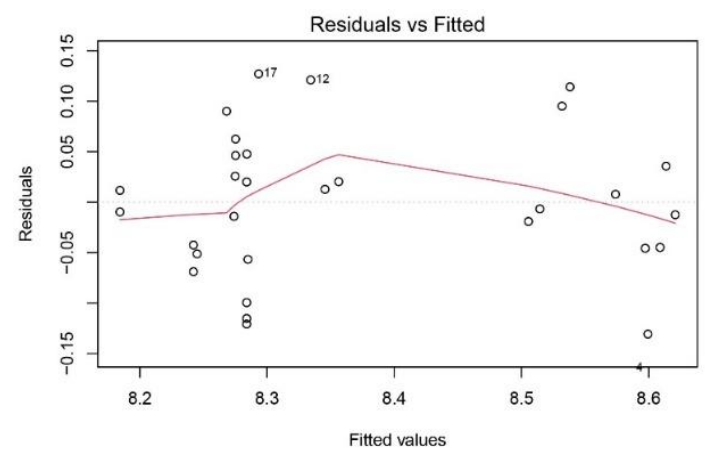

Gambar 2. Grafik Residuals vs Fitted

\section{Uji Autokorelasi}

Menurut [23] uji auto korelasi bertujuan menguji apakah dalam model regresi linear ada korelasi antara kesalahan pengganggu pada periode $\mathrm{t}$ dengan kesalahan pengganggu pada periode t-1 (sebelumnya). [24] menambahkan bahwa pengujian untuk mengetahui masalah auto korelasi yang paling banyak digunakan adalah metode Durbin-Watson.

Pengujian autokorelasi didasarkan pada nilai DW (Durbin Watson), apabila nilai $p$ value $>0,05$ maka tidak terjadi autokorelasi. Berdasarkan hasil analisis, dapat diketahui nilai p-value pada analisis model fungsi produktivitas dan variance produktivitas sebesar 0,2407, artinya $p$-value $>0,05$ sehingga data tersebut dikatakan tidak terjadi autokorelasi. Hasil penelitian [15], menunjukkan bahwa pengujian auto korelasi dengan Durbin-watson test menggunakan software statistik R-studio menghasilkan nilai $p$-value $>$ taraf signifikansi 0,05 sehingga dapat dikatakan residual tidak terjadi auto korelasi.

\section{Uji Multikolinearitas}

Metode yang dapat digunakan untuk menguji terjadinya multikolinearitas dapat dilihat dari matrik korelasi variabel-variabel bebas [25]. Menurut [26], multikolinieritas digunakan untuk mengetahui hubungan linieritas antara variabel bebas. Untuk mendektesi multikolinieritas dalam suatu model dilakukan dengan melihat Variance Inflation Factor (VIF) $[27,20]$. Jika satu set variabel penjelas tidak berkorelasi, maka nilai $\mathrm{VIF}=1$, jika satu set variabel penjelas berkorelasi dengan tingkat yang tinggi maka nilai VIF > 10, sehingga nilai 
VIF 1 sampai dengan $=10$ menunjukkan tidak adanya multikolinieritas [28].

Pengujian terhadap ada atau tidaknya gangguan multikolinieritas dapat dilakukan dengan melihat nilai Tolerance dan nilai VIF. Tabel 1 merupakan nilai Tolerance dan VIF dari hasil regresi fungsi produktivitas rata-rata.

Tabel 1. Nilai Tolerance dan VIF hasil Regresi Linier Berganda

\begin{tabular}{lcc}
\hline \multicolumn{1}{c}{ Variabel } & \multicolumn{2}{c}{ Fungsi Produktivitas Rata-rata } \\
& Tolerance & VIF \\
\hline $\mathrm{X}_{1}$ (pakan buatan) & 0,612082 & 1,633768 \\
$\mathrm{X}_{2}$ (indukan) & 0,600689 & 1,664754 \\
$\mathrm{X}_{3}$ (tenaga kerja) & 0,519502 & 1,924919 \\
$\mathrm{X}_{4}$ (obat-obatan) & 0,543357 & 1,840411 \\
\hline
\end{tabular}

Berdasarkan hasil analisis regresi pada fungsi produktivitas pada Tabel 1, diketahui bahwa nilai tolerance dan Variance Inflation Factor (VIF) pada variabel $\mathrm{X}_{1}$ (pakan buatan), $\mathrm{X}_{2}$ (indukan), $\mathrm{X}_{3}$ (tenaga kerja), dan $\mathrm{X}_{4}$ (obatobatan) masing-masing meiliki nilai $>0,1$ dan < 10. Berdasarkan hal tersebut dapat dikatakan bahwa pada model fungsi produktivitas dan variance produktivitas tidak terjadi multikolinearitas. [16] menambahkan bahwa perhitungan ada tidaknya gejala multikolinearitas menggunakan $\mathrm{R}$-studio dengan output VIF dari semua variabel bebas lebih kecil dari 10, maka dapat disimpulkan bahwa tidak terdapat masalah multikolinearitas antarvariabel bebas.

\section{Uji Linieritas}

Menurut[29], menyatakan bahwa uji lineritas regresi digunakan untuk mengetahui linier atau tidaknya suatu variabel terhadap variabel yang lain. Menurut [26] uji linieritas digunakan untuk mengetahui korelasi antara variabel independen dan variabel dependen. Hubungan antara variabel dikatakan linier adalah variabel yang apabila terjadi perubahan pada suatu variabel maka variabel yang lain akan mengikuti perubahan tersebut. Ada dua teknik yang dapat digunakan untuk uji linieritas yaitu dengan menggunakan compare mean dan scatter plot graph.

Pengujian terhadap ada atau tidaknya hubungan linier antara variabel dependen dan independen dapat dilakukan dengan melihat posisi dua garis warna berbeda (garis putusputus dan garis sambung) berdempetan atau tidak. Berdasarkan hasil analisis, dapat diketahui pada Gambar 3 bahwa pada model fungsi produktivitas dan variance produktivitas tampak posisi dua garis warna berbeda berada pada posisi yang hampir berdempet, artinya variabel independen memiliki hubungan liniearitas dengan variabel dependen sehingga asumsi linieritas model regresi terpenuhi. Sedangkan dilihat secara scatter plot graph, plot yang terbentuk menyebar secara acak atau tidak berbentuk pola sehingga memenuhi syarat linieritas. Hasil penelitian [30] menyatakan bahwa plot yang terbentuk menyebar secara acak serta tersebar baik di atas maupun di bawah angka nol pada sumbu $\mathrm{Y}$ maka dapat disimpulkan memenuhi syarat linieritas. [31] menambahkan bahwa berdasarkan grafik Scatterplot, linearitas terpenuhi apabila plot antara nilai residual ter standarisasi dengan nilai prediksi ter standarisasi tidak berbentuk pola tertentu atau acak.
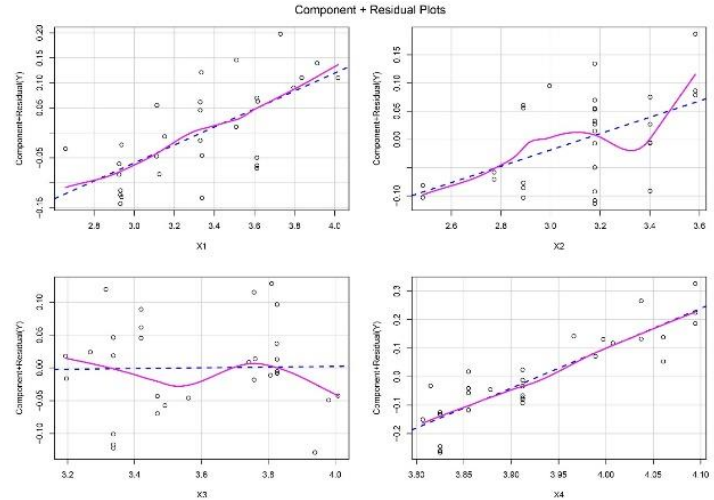

Gambar 3. Grafik Component + Residuals Plots

\section{Faktor-faktor yang Mempengaruhi Produktivitas Benih Ikan Lele Dumbo}

Analisis faktor-faktor yang mempengaruhi produktivitas benih ikan lele dumbo ini dilakukan dengan menjadikan variabel produktivitas sebagai variabel dependennya. Variabel independen yang dimasukkan dalam analisis regresi linier berganda untuk kedua fungsi tersebut adalah variabel pakan buatan $\left(\mathrm{X}_{1}\right)$, indukan $\left(\mathrm{X}_{2}\right)$, tenaga kerja $\left(\mathrm{X}_{3}\right)$, dan obatobatan $\left(\mathrm{X}_{4}\right)$. Tabel 2 merupakan hasil analisis regresi linier berganda fungsi produktivitas.

Tabel 2. Hasil estimasi fungsi produktivitas usaha pembenihan ikan lele dumbo

\begin{tabular}{|c|c|c|}
\hline Variable & Estimate & $\operatorname{Pr}(>|t|)$ \\
\hline (Intercept) & 1.807577 & $0.01448 *$ \\
\hline $\mathrm{X}_{1}$ (pakan buatan) & 0.179969 & $0.00164 * *$ \\
\hline $\mathrm{X}_{2}$ (indukan) & 0.144726 & $0.03096 *$ \\
\hline $\mathrm{X}_{3}$ (tenaga kerja) & 0.005542 & 0.94333 \\
\hline $\mathrm{X}_{4}$ (obat-obatan) & 1.398119 & $2.66 \mathrm{e}-07 * * *$ \\
\hline \multicolumn{3}{|l|}{---} \\
\hline \multicolumn{3}{|c|}{ 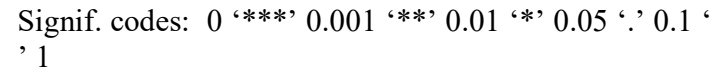 } \\
\hline \multicolumn{3}{|c|}{$\begin{array}{l}\text { Residual standard error: } 0.07608 \text { on } 25 \text { degrees of } \\
\text { freedom }\end{array}$} \\
\hline
\end{tabular}


Berdasarkan hasil estimasi fungsi produktivitas usaha pembenihan ikan lele dumbo yang dicantumkan pada Tabel 2, maka diperoleh persamaan sebagai berikut:

$\mathrm{Y}=1,806+0,180 \ln \mathrm{X}_{1}+0,145 \ln \mathrm{X}_{2}+0,006 \ln \mathrm{X}_{3}$ $+1,398 \ln \mathrm{X}_{4}$

Apabila dikembalikan dalam bentuk semula maka persamaannya menjadi seperti berikut: $\mathrm{Y}=6,096+\mathrm{X}_{1}^{0,180}+\mathrm{X}_{2}{ }^{0,145}+\mathrm{X}_{3}^{0,006}+\mathrm{X}_{4}^{1,398}$

Berdasarkan hasil estimasi model fungsi produktivitas usaha pembenihan ikan lele dumbo yang ditunjukkan Tabel 2 dapat diketahui bahwa nilai $\mathrm{R}^{2}$ (adjusted $R$-square) sebesar 0,7846, ini berarti 78,46 persen variabel variasi produksi benih ikan lele dumbo dapat dijelaskan oleh variasi dari variabel independen (pakan buatan, indukan, tenaga kerja dan obat-obatan), sedangkan sisanya sebesar 21,54 persen dijelaskan oleh variasi dari variabel lain di luar model.

Hasil uji $\mathrm{F}$ (Tabel 2) diperoleh nilai $F$ statistic sebesar 27,41 dengan nilai signifikansi sebesar 8.097e-09. Nilai $F$-statistic lebih besar daripada T-tabel 1,39 pada tingkat $\alpha 0,05$ dan nilai probabilitas signifikansi $F$-statistic kurang dari 0,05. Hal tersebut menunjukkan bahwa semua variabel independen (pakan buatan, indukan, tenaga kerja dan obat-obatan) secara serentak signifikan terhadap produktivitas benih ikan lele dumbo.

Hasil uji t pada penelitian ini, variabel tenaga kerja $\left(\mathrm{X}_{3}\right)$ tidak signifikan terhadap hasil produktivitas benih ikan lele dumbo, hal ini ditunjukkan dengan nilai probabilitas sebesar 0.94333 . Sedangkan untuk jumlah pakan buatan $\left(\mathrm{X}_{1}\right)$, jumlah indukan $\left(\mathrm{X}_{2}\right)$ dan obat-obatan $\left(\mathrm{X}_{4}\right)$ signifikan terhadap hasil produktivitas benih ikan lele dumbo, hal ini ditunjukkan dengan nilai probabilitas masing-masing $\mathrm{X}_{1}=0.00164, \mathrm{X}_{2}=$ 0.03096 dan $\mathrm{X}_{4}=2.66 \mathrm{e}-07$.

\section{Pakan Buatan $\left(\mathbf{X}_{1}\right)$}

Menurut[32], faktor produksi yang nilainya mencapai 60 persen dari total biaya produksi adalah pakan. Berdasarkan hasil analisis regresi, nilai estimasi untuk parameter pakan buatan bernilai positif dengan nilai koefisien 0,180 dan nilai probabilitas sebesar 0.00164 . Nilai tersebut menunjukkan bahwa penambahan penggunaan pakan buatan akan meningkatkan produktivitas benih ikan lele dumbo, cateris paribus. Penambahan pakan buatan sebesar 1 persen akan meningkatkan nilai produktivitas benih ikan lele dumbo sebesar 0,145 persen. Pakan buatan signifikan terhadap produktivitas benih ikan lele dumbo yang dihasilkan oleh pembudidaya responden, hal ini terlihat dari nilai probabilitas pakan buatan sebesar 0.00164 lebih kecil dari taraf nyata 0,05 . Hasil penelitian ini sejalan dengan penelitian [33,34] yang menyatakan bahwa penggunaan pakan berpengaruh signifikan terhadap produksi benih ikan lele dumbo. [35] menambahkan bahwa penggunaan pakan berpengaruh nyata terhadap produksi benih ikan lele sangkuriang. Hasil penelitian [36] mengungkapkan bahwa pelet berpengaruh nyata secara parsial terhadap produksi benih ikan lele. [37,38] menyatakan bahwa dosis pakan memberikan pengaruh secara signifikan terhadap produksi ikan lele.

Pakan buatan yang digunakan oleh pembudidaya responden teridiri dari pakan benih berupa FL-0, FL-1, PF-500, PF-800, LP-1 dan pakan induk PF-128. Menurut [39], pengembangan pakan buatan adalah untuk mencari bahan pakan yang dapat memenuhi kebutuhan protein secara optimal bagi pertumbuhan ikan sehingga penambahan pakan secara tepat dapat meningkatkan produksi ikan. [40] mengungkapkan bahwa pertumbuhan ikan berkaitan secara erat dengan ketersediaan protein dalam pakan, karena protein merupakan nutrisi dan sumber energi yang dibutuhkan ikan untuk pertumbuhan.

\section{Indukan $\left(\mathbf{X}_{2}\right)$}

Indukan merupakan input utama dan pasti digunakan oleh pembudidaya pembenihan ikan lele dalam menjalankan aktivitas produksinya. Masing-masing pembenih ikan lele dumbo memiliki jumlah indukan yang tidak sama dan indukan yang digunakan pembudidaya responden rata-rata memiliki berat $1,5 \mathrm{~kg}-2 \mathrm{~kg}$ per ekor.

Berdasarkan hasil analisis regresi, nilai estimasi untuk parameter indukan bernilai positif dengan nilai koefisien 0,145 dan nilai probabilitas sebesar 0.03096. Nilai tersebut menunjukkan bahwa penambahan penggunaan indukan akan meningkatkan produktivitas benih ikan lele dumbo, cateris paribus. Penambahan indukan sebesar 1 persen akan meningkatkan nilai produktivitas benih ikan lele dumbo sebesar 0,18 persen. Indukan signifikan terhadap produktivitas benih ikan lele dumbo yang dihasilkan oleh pembudidaya responden, hal ini terlihat dari nilai probabilitas indukan sebesar 0.03096 lebih kecil dari taraf nyata 0,05 . Hasil penelitian ini sejalan dengan penelitian [33]yang menyatakan bahwa penggunaan induk 
berpengaruh signifikan terhadap produksi benih ikan lele dumbo. Searah dengan hasil penelitian [36] bahwa indukan berpengaruh nyata secara parsial terhadap produksi benih ikan lele. Pembudidaya responden mendapatkan indukan ikan lele dari pembudidaya ikan lokal seperti daerah pare dan Blitar. Indukan yang digunakan oleh pembudidaya responden rata-rata memiliki berat $2 \mathrm{~kg}$ per ekor dengan umur teknis 3 tahun.

\section{Obat-obatan $\left(\mathbf{X}_{4}\right)$}

Berdasarkan hasil analisis regresi, nilai estimasi untuk parameter obat-obatan bernilai positif dengan nilai koefisien 1,398 dan nilai probabilitas sebesar 2.66e-07. Nilai tersebut menunjukkan bahwa penambahan obat-obatan akan meningkatkan produktivitas benih ikan lele dumbo, cateris paribus. Penambahan obatobatan sebesar 1 persen akan meningkatkan nilai produktivitas benih ikan lele dumbo sebesar 1,398 persen. Penggunaan obat-obatan signifikan terhadap produktivitas benih ikan lele dumbo yang dihasilkan oleh pembudidaya responden, hal ini terlihat dari nilai probabilitas obat-obatan sebesar 2.66e-07 lebih kecil dari taraf nyata 0,05 . Hasil penelitian ini sejalan dengan penelitian [41] yang menunjukkan bahwa penggunaan obat-obatan berpengaruh secara nyata terhadap produktivitas benih ikan neon tetra pada taraf nyata 0.150 . Hasil penelitian [42], mengungkapkan bahwa biaya vitamin dan obat-obatan berpengaruh secara nyata terhadap pendapatan pembudidaya ikan lele dumbo pada taraf nyata 0,05 . Searah dengan hasil penelitian [36] bahwa probiotik berpengaruh nyata secara parsial terhadap produksi benih ikan lele. Hasil penelitian [43] juga mengungkapkan bahwa hasil pengujian variabel obat-obatan berpengaruh signifikan terhadap pendapatan bersih usaha tani ikan Koi. Obat-obatan yang digunakan oleh pembudidaya responden adalah boster inrofloxs-25 dan furazolidone (obat kuning). Obat-obatan merupakan faktor penting untuk menunjang pertumbuhan dan daya tahan benih ikan lele terhadap bakteri dan penyakit.

\section{Faktor - Faktor yang Mempengaruhi Risiko Produksi Benih Ikan Lele Dumbo}

Pengujian yang dilakukan untuk mengetahui pengaruh dari faktor-faktor produksi yang mencakup pakan buatan $\left(\mathrm{X}_{1}\right)$, jumlah indukan $\left(\mathrm{X}_{2}\right)$ dan obat-obatan $\left(\mathrm{X}_{4}\right)$ terhadap variabel variance produktivitas adalah uji determinasi $\mathrm{R}^{2}$, uji $\mathrm{F}$, dan uji t. Tabel 3 merupakan hasil pendugaan fungsi variance produktivitas benih ikan lele yang dilakukan pembudidaya responden di Desa Joho Kecamatan Wates.

Tabel 3. Hasil estimasi fungsi variance produktivitas usaha pembenihan ikan lele dumbo

\begin{tabular}{lrr}
\hline \multicolumn{1}{c}{ Variable } & Estimate & \multicolumn{1}{c}{$\operatorname{Pr}(>|\mathbf{t}|)$} \\
\hline (Intercept) & $-31,3405$ & 0,2510 \\
$\mathrm{X}_{1}$ (pakan buatan) & 3,0008 & 0,1415 \\
$\mathrm{X}_{2}$ (indukan) & $-5,0988$ & $0,0481 *$ \\
$\mathrm{X}_{3}$ (tenaga kerja) & $-0,5132$ & 0,8652 \\
$\mathrm{X}_{4}$ (obat-obatan) & 16,2424 & $0,0472 *$ \\
\hline
\end{tabular}

Signif. codes: 0 '***' 0,001 '**' 0,01 '*' 0,05 '? 0,1 ' , 1

Residual standard error: 2.95 on 25 degrees of freedom Multiple R-squared: 0,3375

Adjusted R-squared: 0,2315

F-statistic: 3,184 on 4 and 25 DF, p-value: 0,03036

Berdasarkan hasil estimasi terhadap fungsi variance produktivitas usaha pembenihan ikan lele dumbo yang dicantumkan pada Tabel 3, maka diperoleh persamaan sebagai berikut:

$\sigma^{2}{ }_{Y}=-31.3405+3,001 \ln X_{1}-5,099 \ln X_{2}-0,513$ $\ln X_{3}+16,242 \ln X_{4}$

Apabila dikembalikan dalam bentuk semula maka persamaannya menjadi seperti berikut: $\sigma^{2} \mathrm{Y}=2,44903 \mathrm{E}-14+\mathrm{X}_{1}^{3,001}+\mathrm{X}_{2}^{5,099}+\mathrm{X}_{3}^{0,513}+$ $\mathrm{X}_{4} 16,242$

Berdasarkan hasil estimasi model fungsi variance produktivitas usaha pembenihan ikan lele dumbo yang ditunjukkan Tabel 3 dapat diketahui bahwa nilai $\mathrm{R}^{2}$ (adjusted R-square) sebesar 0,2315, ini berarti 23,15 persen keragaman atau variasi dari variabel variance produktivitas usaha pembenihan ikan lele dumbo dapat dijelaskan oleh variasi dari variabel independen (pakan buatan, indukan, tenaga kerja dan obat-obatan), sedangkan sisanya sebesar 76,85 persen dijelaskan oleh variasi dari variabel lain di luar model.

Hasil uji $\mathrm{F}$ (Tabel 3) diperoleh nilai $F$ statistic sebesar 3,184 dengan nilai signifikansi sebesar 0,03036. Nilai F-statistic lebih besar daripada T-tabel 1,39 pada tingkat $\alpha 0,05$ dan nilai probabilitas signifikansi $F$-statistic kurang dari 0,05 . Hal tersebut menunjukkan bahwa semua variabel independen (pakan buatan, indukan, tenaga kerja dan obat-obatan) secara serentak signifikan terhadap variance produktivitas usaha pembenihan ikan lele dumbo.

Hasil uji t menunjukkan bahwa variabel pakan buatan $\left(\mathrm{X}_{1}\right)$ dan tenaga kerja $\left(\mathrm{X}_{3}\right)$ tidak signifikan terhadap variance produktivitas benih ikan lele dumbo, hal ini ditunjukkan dengan nilai probabilitas masing-masing variabel sebesar 
0,1415 dan 0,8652 . Sedangkan untuk jumlah indukan $\left(\mathrm{X}_{2}\right)$ dan obat-obatan $\left(\mathrm{X}_{4}\right)$ signifikan terhadap variance produktivitas benih ikan lele dumbo, hal ini ditunjukkan dengan nilai probabilitas masing-masing sebesar 0,0481 dan 0,0472 .

\section{Indukan $\left(\mathbf{X}_{2}\right)$}

Berdasarkan hasil perhitungan software statistik, nilai estimasi untuk parameter indukan bernilai negatif dengan nilai koefisien 5,099 dan nilai probabilitas sebesar 0,0481 . Nilai tersebut menunjukkan bahwa penambahan penggunaan indukan akan mengurangi nilai varianceproduktivitas benih ikan lele dumbo, cateris paribus. Indukan menjadi salah satu faktor produksi yang menurunkan risiko produksi (risk reducing factors). Penambahan indukan sebesar 1 persen akan menurunkan nilai variance produktivitas benih ikan lele dumbo sebesar 3,001 persen. Penambahan indukan signifikan terhadap variance produktivitas benih ikan lele dumbo yang dihasilkan oleh pembudidaya responden, hal ini terlihat dari nilai probabilitas indukan sebesar 0,0481 lebih kecil dari taraf nyata 0,05 . Hasil penelitian ini sejalan dengan hasil penelitian yang dilakukan oleh [41], dimana secara signifikan penambahan penggunaan indukan akan mengurangi nilai variance produktivitas benih ikan neon tetra.

Sebagian besar pembudidaya responden memiliki indukan dengan umur teknis rata-rata 3 tahun, setelah mencapai umur tersebut maka indukan memiliki kualitas dan kuantitas matang gonad yang terbatas sehingga mempengaruhi produktivitas benih ikan yang dihasilkan. Oleh karena itu, pembudidaya responden akan mengganti dengan indukan baru yang dibeli dari pembudidaya ikan lokal sehingga penambahan atau penggantian penggunaan indukan akan menurunkan risiko produksi benih ikan lele dumbo. Menurut [2], faktor kualitas induk dan musim sangat berpengaruh terhadap peningkatan produksi benih. Salah satu faktor pembatas utama dalam pengembangan budidaya ikan lele untuk skala massal adalah frekuensi induk memijah rendah, kualitas dan kuantitas induk yang matang gonad terbatas sehingga benih yang dihasilkan tidak berkesinambungan. Frekuensi induk memijah rendah dikarenakan ikan lele pada umumnya memijah pada musim hujan sehingga di luar musim pemijahan (musim kemarau), ikan ini sulit memijah.

\section{Obat-obatan $\left(\mathbf{X}_{4}\right)$}

Berdasarkan hasil perhitungan software statistik, nilai estimasi untuk parameter obatobatan bernilai positif dengan nilai koefisien 16,242 dan nilai probabilitas sebesar 0,0472. Nilai tersebut menunjukkan bahwa penambahan penggunaan obat-obatan akan meningkatkan nilai varianceproduktivitas benih ikan lele dumbo, cateris paribus. Obat-obatan menjadi salah satu faktor produksi yang meningkatkan risiko produksi (risk inducing factors). Penambahan obat-obatan sebesar 1 persen akan meningkatkan nilai variance produktivitas benih ikan lele dumbo sebesar 16,242 persen. Penambahan obat-obatan signifikan terhadap variance produktivitas benih ikan lele dumbo yang dihasilkan oleh pembudidaya responden, hal ini terlihat dari nilai probabilitas obat-obatan sebesar 0,0472 lebih kecil dari taraf nyata 0,05. Hasil penelitian ini sejalan dengan penelitian [44], dimana parameter variabel obat-obatan memiliki tanda positif, artinya peningkatan penggunaan obat-obatan pada proses produksi maka variasi hasil produksi udang windu akan meningkat. Dalam arti lain, penggunaan obatobatan dapat menimbulkan risiko.

Pembudidaya responden menggunakan obat-obatan seperti boster inrofloxs-25 dan furazolidone (obat kuning) untuk mengurangi potensi benih ikan lele dumbo yang terserang bakteri dan penyakit. Namun, dosis penggunaan obat-obatan tidak boleh melebihi batas yang sudah dianjurkan baik untuk pencegahan maupun pengobatan ikan. Artinya penggunaan obat-obatan yang terlalu banyak berpotensi meningkatkan risiko produksi berupa ikan menjadi overdosis dan menyebabkan kematian.

\section{KESIMPULAN}

Faktor atau input produksi pakan buatan, indukan dan obat-obatan signifikan terhadap produktivitas benih ikan lele dumbo. Nilai estimasi semua parameter bertanda positif yang menunjukkan bahwa penambahan input produksi akan meningkatkan produktivitas benih ikan lele dumbo, cateris paribus. Pakan buatan yang digunakan oleh pembudidaya responden teridiri dari pakan benih berupa FL-0, FL-1, PF-500, PF-800, LP-1. Penggunaan pakan buatan dapat memenuhi kebutuhan protein secara optimal bagi pertumbuhan ikan sehingga penambahan pakan secara tepat dapat meningkatkan produksi benih ikan. Indukan yang digunakan oleh pembudidaya responden rata-rata memiliki berat $2 \mathrm{~kg}$ per ekor, umur teknis rata-rata di bawah 3 tahun dan tingkat 
kematangan gonad yang cukup baik sehingga indukan mampu meningkatkan produksi benih ikan. Sedangkan obat-obatan yang digunakan oleh pembudidaya responden adalah boster inrofloxs-25 dan furazolidone (obat kuning). Obat-obatan tersebut untuk menunjang pertumbuhan dan meningkatkan daya tahan benih ikan lele terhadap bakteri dan penyakit.

Penambahan indukan secara signifikan menurunkan risiko produksi (risk reducing factors). Indukan yang sudah mencapai umur teknis 3 tahun memiliki kualitas dan kuantitas matang gonad yang terbatas, sehingga penambahan atau penggantian penggunaan indukan baru akan menurunkan risiko produksi benih ikan lele dumbo. Sedangkan obat-obatan secara signifikan meningkatkan risiko produksi (risk inducing factors). Pembudidaya responden menggunakan obat-obatan untuk mengurangi potensi benih ikan lele dumbo yang terserang bakteri dan penyakit. Penggunaan obat-obatan yang terlalu banyak berpotensi meningkatkan risiko produksi berupa ikan menjadi overdosis dan menyebabkan kematian

Saran bagi pembudidaya benih ikan lele dumbo adalah pembatasan penggunaan faktor atau input produksi yang dapat menimbulkan risiko produksi sudah seharusnya dilakukan, penerapan CBIB (Cara Budidaya Ikan yang Baik) berdasarkan atas kebijakan dari Direktorat Jenderal Perikanan Budidaya (DJPB) yang berada di bawah Ketentuan Peraturan Menteri.

\section{UCAPAN TERIMA KASIH}

Terima kasih kami sampaikan kepada Lembaga Penelitian dan Pengabdian kepada Masyarakat (LPPM) Universitas Brawijaya yang telah memberikan dukungan dana melalui program Hibah Peneliti Pemula Tahun Anggaran 2020, Dinas Perikanan Kabupaten Kediri, serta Pokdakan Berkah Lele dan Sumber Rejeki.

\section{DAFTAR PUSTAKA}

[1] Dinas Perikanan dan Kelautan Jawa Timur. 2014. Laporan Tahunan Statistik Perikanan Budidaya di Jawa Timur Tahun 2014.

[2] Adebayo, O., \& Fagbenro, O. (2004). Induced Ovulation and Spawning of Pond Raised African Giant Catfish, Heterobranchus Bidorsalisby Exogenous Hormones. Aquaculture, 242(1-4), 229236, Des 2004.
[3] Hartoyo, K. L., \& Fariyanti, A. (2018). Risiko dan Strategi Peningkatan Produksi Udang Vannamei di Kecamatan Blanakan Kabupaten Subang. Jurnal Sosek KP, 13(1), 99-110, Jun 2018.

[4] Asche, F., \& Tveterås, R. (1999). Modeling Production Risk with a TwoStep Prosedure. Journal of Agricultural and Resource Economics, 24(2), 424-439, Des 1999.

[5] Cooper, D. R., \& Emory, C. (1996). Business Research Methods. New York: Richard D Irwin.

[6] Just, R. E., \& Pope, R. D. (1979). Production Function Estimation and Related Risk Considerations. American Journal of Agricultural Economics, 61(2), 276-284, Mei 1979.

[7] Asmara, R., Widyawati, W., \& Hidayat, A. H. (2019). Preferensi Resiko Petani dalam Alokasi Input Usahatani Jagung Menggunakan Model Just nnd Pope. Jurnal Ekonomi Pertanian dan Agribisnis (JEPA), 3(2), 449-459, Apr 2019.

[8] Rama, R., Nurliza, \& Doloroza, E. (2016). Analisis Risiko Produksi Usahatani Padi Lahan Basah dan Lahan Kering di Kabupaten Melawi. Jurnal Social Economic of Agriculture, 5(1), 73-88, Mei 2016.

[9] Ghozali, I. (2009). Ekonometrika Teori, Konsep, dan Aplikasi dengan SPSS 17. Semarang: Badan Penerbit Universitas Diponegoro.

[10] Zuur, A. F., Ieno, E. N., Walker, N., Saveliev, A. A., \& Smith, G. M. (2009). Mixed Effects Models and Extensions in Ecology with $R$. New York: Springer Science + Business Media.

[11] Shapiro, S. S., \& Wilk, M. B. (1965). An Analysis of Variance Test for Normality (Complete Samples). Biometrika, 52(3/4), 591-611, Des 1965.

[12] Ayuningtyas, A. D. (2012). Kekuatan Efisiensi Uji Normalitas KolmogorovSmirnov dan Shapiro-Wilk pada Sasaran 
Program KB di Provinsi Jawa Timur Tahun 2010. Surabaya: Universitas Airlangga.

[13] Dahlan, M. S. (2009). Statistik untuk Kedokteran dan Kesehatan (Edisi 4 (Deskriptif, Bivariat dan Multivariat, dilengkapi Aplikasi dengan Menggunakan SPSS) ed.). Jakarta: Salemba Medika.

[14] Razali, N. M., \& Wah, Y. B. (2011). Power comparisons of Shapiro-Wilk, Kolmogorov-Smirnov, Lilliefors and Anderson-Darling Tests. Journal of Statistical Modeling and Analytics, 2(1), 21-33, Jan 2011.

[15] Azkia, M. W., Hitayuwana, N., Khusna, Z. A., \& Widodo, E. (2019). Analisis Temperature Dan Kelembaban Terhadap Curah Hujan Di Kabupaten Sleman Provinsi Daerah Istimewa Yogyakarta (Studi Kasus: Temperature, Kelembaban, Dan Curah Hujan Di Kabupaten Sleman). Seminar Nasional Teknologi Creative and Innovative Education in the Industry 4.0 : teh Current Trends (hal. 77-85). Yogyakarta: UNY Press, Mar 2019.

[16] Ahsani, F. T., \& Ardian, D. (2020). Analisis Faktor yang Memengaruhi Swasembada Beras di Indonesia Tahun 2018. Seminar Nasional Official Statistics 2019 : Pengembangan Official Statistics dalam Mendukung Implementasi SDG's.2019 (1), hal. 196-201. Jakarta: Politeknik Statistika STIS, Mei 2020.

[17] Uthami, I. P., Sukarsa, I. G., \& Kencana, I. E. (2013). Regresi Kuantil Median untuk Mengatasi Heteroskedastisitas Pada Analisis Regresi. e-Jurnal Matematika, 2(1), 6-13, Jan 2013.

[18] Andriani, S. (2017). Uji Park dan Uji Breusch Pagan Godfrey dalam Pendeteksian Heteroskedastisitas pada Analisis Regresi. Al-Jabar: Jurnal Pendidikan Matematika, 8(1), 63-72, Jun 2017.

[19] Winarno, W. W. (2009). Analisis Ekonometrika dan Statistika dengan Eviews. Yogyakarta: UPP Sekolah Tinggi Ilmu Manajemen YKPN.
[20] Thomas, R. L. (1997). Modern Economometrics an Introduction. Harlow: Addison Wesley Longman.

[21] Verbeek, M., Leuven, K., \& University, T. (2000). A Guide to Modrn Econometrics. Chichester: Jonh Wiley and Sons Ltd.

[22] Effendi, R., Maiyastri, \& Diana, R. (2019). Perbandingan Metode Regresi Kuantil dan Metode Bayes dalam Mengestimasi Parameter Model Regresi Linier Sederhana dengan Galat Heteroskedastisitas. Jurnal Matematika Unand, 8(1), 291-298, Mei 2019.

[23] Ghozali, I. (2013). Aplikasi Analisis Multivariate dengan Program SPSS (7 ed.). Semarang:BadanPenerbitUniversitas Diponegoro.

[24] Yuwono, P. (2005). Pengantar Ekonometri. Yogyakarta: CV. Andi Offset.

[25] Gujarati, D. N., \& Porter. (2009). DasarDasarEkonometrika.Jakarta:SalembaEm pat.

[26] Alhusin, S. (2003). Aplikasi Statistik Praktis dengan SPSS.10 for Windows. Yogyakarta: Graha Ilmu.

[27] Hanke, J. E., Wichern, D. W., \& Reitsch , A. G. (2001). Business Forecasting (7 ed.). Upper Saddle River, New Jersey: Prentice-Hall, Inc.

[28] Hakim, A. (2004). Statistika Deskriptif Untuk Ekonomi dan Bisnis. Yogyakarta: Ekonisia.

[29] Sudjana. (2005). Metode Statistika. Bandung: Tarsito.

[30] Fitriyani, H. A. (2019). Pengaruh Net Profit Margin (NPM) dan Biaya Operasional Pendapatan Operasional (BOPO) Terhadap Return on Assets (ROA) (pada Perusahaan Transportasi yang Terdaftar di Bursa Efek Indonesia Tahun 2013-2015). Jurnal Bisnis dan Akuntansi Unsurya, 4(2), 94-106, Jun 2019. 
[31] Sundarsih, D., \& Andriati, Y. S. (2020). Analisis Ukuran Perusahaan Dalam Meningkatkan Profitabilitas (Survey pada PT Sekar Bumi Tbk). BanKu: Jurnal Perbankan dan Keuangan, 1(1), 38-45, Feb 2020.

[32] Mahyudin, K. (2008). Panduan Lengkap Agribisnis Lele. Jakarta: Penebar Swadaya.

[33] Pramono, M. D., Ferichani, M., \& Rahayu, E. S. (2017). The Analysis of Factors Influence Catfish Seed (Clarias Gariepenus) Production in Wonogiri District. American Scientific Research Journal for Engineering, Technology, and Sciences (ASRJETS), 28(1), 30-48, Feb 2017.

[34] Robby, A. N., Arsyad, A., \& Yusdiarti, A. (2015). Analisis Pendapatan dan Faktorfaktor Produksi yang Mempengaruhi Usaha Budidaya Pembenihan Ikan Lele Dumbo di Kecamatan Ciseeng Bogor. Jurnal AgribiSains, 1(1), 30-37, Apr 2015.

[35] Sundari, R. S., \&Priyanto, Y. A. (2016). Efficiency Of Production Factors Application on Catfish (Clarias sp) Var. Sangkuriang Hatchery Technology. Jurnal Teknologi Perikanan dan Kelautan, 7(2), 200-207, Nov 2016.

[36] Kusumawati, I. H. (2015). Analisis Fungsi Produksi Cobb-Douglas pada Usaha Pembenihan Ikan Lele (Clarias sp.) di Kabupaten Kediri, Jawa Timur. Malang: Universitas Brawijaya.

[37] Dewi , D. K., \& Mulyo, J. H. (2015). Production Analysis of Catfish (Clarias gariepinus) Farming: Cobb Douglas Production Function. Jurnal Perikanan ( $J$. Fish. Sci.), XVII(2), 54-60, Jul 2015.

[38] Sumartin. (2017). Efisiensi Faktor Faktor Produksi Usaha Budidaya Ikan Lele
Dumbo (Clarias gariepinus): Studi Kasus pada Alumni Peserta Pelatihan Budidaya Ikan di BPPP Banyuwangi). Samakia: Jurnal Ilmu Perikanan, 8(2), 6-16, Okt 2017.

[39] Khairuman, \& Amri, K. (2002). Membuat Pakan Ikan Konsumsi. Jakrta: Agro Media Pustaka.

[40] Anggraeni, N. M., \& Abdulgani, N. (2013). Pengaruh Pemberian Pakan Buatan dan Pakan Alami Terhadap Pertumbuhan Ikan Betutu pada Skala Laboratorium. Jurnal Sains dan SeniPomits, 2(1), $197-$ 201, Sep 2013.

[41] Nauli, M. L. (2016). Analisis FaktorFaktor yang Mempengaruhi Risiko Produksi Benih Ikan Neon Tetra di Kecamatan Bojongsari, Kota Depok. Institut Pertanian Bogor. Bogor: Fakultas Ekonomi dan Manajemen.

[42] Fauziah, A. F., Agustina, T., \& Hariyati, Y. (2016). AnalisisPendapatan dan PemasaranIkanLele Dumbo di DesaMojomulyoKecamatanPuger. JSEP, 9(1), 20-36, Mar 2016.

[43] Ruby, I., \& Sasongko. (2017). Analisis Produksi Optimum Usaha Tani Ikan Koi (Studi pada Kecamatan Sanankulon, Kabupaten Blitar). Jurnal Ilmiah Mahasiswa Fakultas Ekonomi dan Bisnis, 5(2).

[44] Sinaga, V. R. (2011). Analisis Risiko Faktor-Faktor produktivitas Udang Windu (Penaeus monodon) pada Petambak Tradisional di Desa Pusakajaya Utara Kabupaten Karawang. Institut Pertanian Bogor. Bogor: Departemen Agribisnis Fakultas Ekonomi dan Manajemen. 